\title{
The Relationship between Work Motivation, Burnout and Intention to Leave for the Middle Level Managers of Garment Industry (A Case Study of Indian Garment
} Industry)

\author{
Dr. Seema Qureshi \\ Assistant Professor in College of Business administration \\ Dar al Uloom University, Riyadh, Saudi, Arabia \\ E-mail: seemaqureshi2003@yahoo.co.in
}

Received: Dec. 2, 2013 Accepted: Dec. 12, 2013 Published: Dec. 16, 2013

doi:10.5296/bmh.v1i2.4779 URL: http://dx.doi.org/10.5296/bmh.v1i2.4779

\begin{abstract}
Middle level managers are expected to play a critical role in translating organizational policies and strategies into practice and action. They have an important role in providing information/input to strategy formulation, and in motivating and energizing employees at lower levels but studies in some large Indian organization in both the public and the private sector show that these managers themselves feel like "victims" and experience a sense of powerlessness in their organizations; they are the ones who express the most negative emotions about any organizational change effort; they feel a sense of stagnation in terms of real personal and professional growth in spite of receiving promotions at fairly predictable intervals; they assume a 'spectator' rather than an 'actor' stance in the organization; and they do not see themselves as a part of the "real" management. As a result, the middle and senior management performance remains far below the potential. Taking into consideration the importance of middle managers in the organization and a critical review of literature which revealed that the study on work motivation, burnout and intention to leave has not been conducted so far on the middle level managers of garment industry of Delhi and NCR (India), the researcher found a gap to be filled by conducting an investigation on this sample for the variables in question. So the sample of the present study consists of the middle level managers of garment industry of Delhi and NCR (India).
\end{abstract}

Thus, a convenient sampling method was used for drawing the sample from 60 garment export houses of Delhi and 40 of NCR (India). 


\section{Macrothink}

Business and Management Horizons

ISSN 2326-0297

2013, Vol. 1, No. 2

This paper gives a deep insight of work motivation, burnout and intention to leave for the middle level managers of the garment industry of Delhi/NCR (India). In this paper the researcher has checked the relationship of all dimensions of work motivation with the dimensions of burnout and intention to leave and have observed that all dimensions of work motivation have some more or less relationship with each dimension of burnout and intention to leave.

Keywords: Middle level managers, Work motivation, Burnout, Intention to leave, Delhi/NCR (India) 


\section{Introduction}

Work Motivation perhaps is the single most important factor that concerns each and every executive today. The word "motivation" comes from Latin word "movere" meaning to move. Motivation is inner bearing passion caused by needs, wants and desire which propels an employee to exert his physical and mental energy to achieve desired objectives. The industry frequently offers the employee's external incentives such as pay, and reprimands, these, however, are less successful than incentives which motivate people internally. External motivation stimulated by pay, praise or punishment is supportive only if it is internalized. Internal motivation is that which starts from ego, needs of the person.

In Garment industry employers uses visual aids-charts of production, first pass yield, orders filled, etc. as a great motivator and quality is also used as a factor in promotions or grade changes-from operator to senior operator if you use job grade.

Management provides many stimuli to motivate people at work. Several motives may be operating at once. When a motive is present in person it will become active when there is some appealing reason. Management's problem is to induce employees to express their motives in productive work and to prevent frustration resulting from blocked expression of these motives. So it is very important for management to know that what motivates its employees because when employees have high work motivation, there will be high job satisfaction as a result of which there will be up to mark performance, less stress and less turnover.

The topic of burnout began to gain attention in the mid (1970s) with a book by Freudenberger (1974). He originally defined 'burnout' as "the extinction of motivation or incentive, especially where one's devotion to a cause or relationship fails to produce the desired results .As a clinician, he reported a number of cases studies burnout, particularly in the human services professions; his focus was on the psychodynamics of the problem. He defined burnout as a state of physical and emotional depletion resulting from conditions of work (Freudenberger and North, 1985). Burnout is a process that occurs when workers perceive a discrepancy between their work input and the output they had expected from work. According to Maslach (1993), burnout is a multidimensional construct of emotional exhaustion, depersonalization, and reduced personal accomplishment that can occur among individuals who work extensively with others under considerable time pressures. Furthermore, burnout is particularly relevant to individuals when working with people in emotionally charged situations. Much of the research conducted on burnout has been done with the proposed definition of burnout put forth by Maslach (1993) and her colleagues. Ultimately Maslach (1993) proposed that there are three specific symptoms of burnout. Emotional exhaustionis that feeling of being "used up" and unable to face another day. That feeling prompts individuals to emotionally and cognitively distance themselves from their work as a way to cope. Depersonalization is characterized by a negative shift in response to person's problems. In other words, one begins to expect the worst from the person or begins to treat him as a "case" or a "number," distancing oneself from him. Reduced sense of personal accomplishment is characterized by a negative shift in response toward oneself and the work that one does as a result of pressures on the job. Reduced personal accomplishment or a sense of reduced professional efficacy leads to an overall sense of 
ineffectiveness. Experiencing any one of these three symptoms is manageable to some extent; however, when individuals begin to exhibit all three symptoms, they have reached burnout. Burnout develops gradually over time and is the result of excessive demands and limited resources to meet those demands (Tony \& Lilian, 2012)

All these definitions embrace the essence of burnout, with the first stressing the part that exhaustion plays in it, and the second stressing the sense of disillusionment that is at its core.

The concept of intention to leave has been described by various research scholars in their own styles. Intention to leave refers to an individual's perceived probability of staying or leaving an employing organization (Cotton \& Tuttle, 1986). Tett and Meyer (1993), on the other hand, referred to turnover intentions as a conscious and deliberate willfulness to leave the organization. Lack of work motivation and turnover among employees may be major contributors to intention to leave. Moreover, turnover is often the result of what happens to managers after they become burned-out. Turnover is both a cause, and an effect of burnout. One of the main financial benefits of turnover is that it provides an opportunity to reset salaries. As employees at the high end of the pay structure leave, cost savings are typically seen when a company brings in a replacement at a lower rate, or promotes from within and lowers the rate for that employee's replacement. Some employee turnover positively benefits organizations. This happens whenever a poor performer is replaced by a more effective employee, and can happen when a senior retirement allows the promotion or acquisition of welcome 'fresh blood'.

\section{Literature Review}

The present researcher has made an attempt to come out with a brief review of studies done on work motivation, burnout and intention to leave. Many theoretical and empirical studies tried to analyze the relationship of these variables separately or in conjunction with each other on different samples with different modeling approaches. Most of the available literature on work motivation, burnout and intention to leave is of recent origin. The survey relates to the period from 1950's to 2012.

There is no dearth of researches on work motivation. Many scholars have worked on these variables and have come up with different observation and conclusions. It has been observed that intrinsic as well as extrinsic factors contribute to work motivation, in which money, work environment, and work group relations also play an important role. Burnout is also a complex problem which all employees at all levels face within an organization. Almost one-fifth of managers experience high levels of burnout in organizations and the reason being for burnout are usually the organizational factors that contribute to employees frustration with their work situation. Intention to leave mainly crops up due to low work motivation and high burnout. It has been found by researchers that employees usually intend to leave when they are emotionally exhausted, have lower levels of intrinsic job satisfaction and are dissatisfied with their salary and promotion opportunities. One of the key findings from the review of literature shows that consistent employee recognition is rated very highly among employees as a factor influencing retention. This is consistent with industry research, which also identifies recognition as a key factor in retaining top-performing workers. These important findings, coupled with the human resources department's strategic goals, generated actions to increase 
employee recognition. Similarly individual characteristics reflecting demographic and work factors, contextual variables reflecting the individual stature and adjustment to the work environment also play an important role in employee's intention to leave the organization.

The researches which have been done till date on work motivation, burnout and intention to leave variables are presented as follows under their respective headings.

\subsection{Work Motivation}

Winter (2000) identified positive and negative sources of work motivation. It was found that when roles are clear, job tasks are challenging and supervisors exhibit a supportive leadership style, the work environment is motivating and when there is role overload, low participation and poor rewards and recognition practices the work environment is de-motivating and henceforth low work motivation. Pool \& Steven (1997) administered a questionnaire to 125 adults to examine the predictive values of substitutes of leadership, leadership behavior and work motivation in relation to job satisfaction. Substitutes of leadership refer to variety of individual task, and organizational factors that influence the relationship between a leader's behavior and a subordinate's job satisfaction. In the stepwise analysis task substitutes, organizational substitutes, consideration leadership styles, and initiating structure leadership style and work motivation were significant and together accounted for $53 \%$ of the total variance of job satisfaction in both the stepwise and independent regression analysis. Work motivation and consideration leadership style were the highest predictors of job satisfaction for the aggregate population by occupation. In the step wise analysis work motivation was the highest predictor of job satisfaction for executives, middle managers and workers. In the independent for executives, work motivation was the best predictor of job satisfaction. Trist \& Bamforth (1951) recognized the importance of social environment for employee's outcomes. On motivational work characteristics two social characteristics of work-dealing with others and friendship opportunities were identified and examined. Although it was found that these social characteristics related to satisfaction, lack of relationships, with behavioral outcomes of motivation and tempered enthusiasm. For work motivation it is necessary to create an environment that meets the motivational needs of the wide range of individuals within the profession so as to avoid social burnout.

\subsection{Burnout}

Lamude \& Furno (1996) focused on whether perception of burnout, measured by the Cherniss Burnout Scale, is related to managers' self-reported tactics of influence with subordinates. Contrary to expectations, analysis of the scores of 209 managers from 47 organizations indicated rational, ingratiating, and inspirational appeals, consultation, and exchange tactics of influence were positively correlated with burnout, whereas scores on pressure and legitimacy were negatively correlated with burnout, scores. Densten \& Iain L. (2005) investigated that whether the perceived visioning behaviors of leaders influence the burnout process experienced by their followers. A structural equation model was used to examine these relationships using a sample of 480 senior managers from an Australian law-enforcement organization. Differences in the relationships between the two factors of visioning behavior and aspects of burnout were identified. Inspirational motivation (concept-based) reduced the 
central factor of burnout, namely emotional exhaustion (psychological strain). Inspirational motivation (image based) had a positive effect on personal accomplishment (self) and reduced depersonalization. From an employee's perspective, the organization helps meet an employee's need for appreciation, admiration, and attachment (Boyas \& Wind, 2010). “Supervisor support includes informational, instrumental, and appraisal support elements; such as, encouragement to employees to put forth their best efforts” (Gray-Stanley \& Muramatsu, 2011,). Support from coworkers includes "informational, instrumental, and emotional support elements, such as the extent to which coworkers can back each other up with work duties” (Gray-Stanley \& Muramatsu). Informational support refers to the provision of advice, guidance, suggestions, or useful information to someone. Instrumental support, also referred to as tangible support, is the provision of financial assistance, material goods, or services. It encompasses the concrete and direct ways people assist each other. Emotional support is the offering of empathy, concern, trust, acceptance, and encouragement

\subsection{Intention to Leave}

Jacob (1994) conducted a research on the relationship between the burnout of female school teachers and its effect on their intentions to leave their jobs. Based on a comparative analysis of three measures of burnout, showed two major findings. First, the best burnout predictor of intention to leave a job was obtained when 21 items measuring burnout level were factorily analyzed and consolidated into three factors, which were then employed as independent variables in a regression analysis. This was superior to the utilization of the mean score of the 21 items or to a single direct measure. Explained variances were 66.5 per cent, 55.7 per cent, and 44.5 per cent, respectively. Second, a more detailed identification of types of burnout obtained by the first method showed that physical and mental burnout components were significant in explaining workers' intention to leave, while emotional burnout was not. Catherine (2002) examined annual turnover rates in private clubs and the reasons that employees left their jobs, as perceived by management. Members of the Club Managers Association of America were randomly selected and surveyed. The analysis compared turnover and managers' perceptions of reasons for turnover with: manager's years of experience in current position; years of experience in the industry; club type; club size; and whether or not the manager had a hospitality management degree. The results conclude that it is crucial for team managers to develop a team environment in the workplace to increase club loyalty, ultimately reducing employee turnover. Highlighted factors within a manager's control which are strongly limited to employee turnover in private clubs.

Houkes. I. (2001) found that there is a specific relationship between work motivation, burnout \& intention to leave. This study of two different samples (245 bank employees and 362 teachers) tested a theoretically derived pattern of specific relationships between work stressors and outcome variables. The research model proposes four central domains of the work situation: work content, working conditions, social and labor relations, and conditions of employment. In addition, the research model proposes three important outcome variables: intrinsic work motivation, emotional exhaustion, and turnover intention. More specifically, it was hypothesized that: (1) intrinsic work motivation is primarily predicted by task characteristics; (2) emotional exhaustion is primarily predicted by both workload and lack of 
social support; (3) turnover intention is primarily predicted by unmet career expectations; and (4) the proposed pattern of relationships holds over different groups. The results indicated that employees who have higher level of satisfaction are less likely to quit their jobs, they are also less willing to opt for other jobs, they remain present in their job and their absenteeism rate is much low then other workers. This in return saves various costs of organizations like recruitment and selection cost, as new hiring would not be required. Similarly, it will save training cost as the existing workforce would be more knowledgeable (Smith, 1992). Positive attitude (job satisfaction) of an employee towards his job has significant relationship with increased effectiveness, reduced absenteeism and reduced turnover of the employees in the organization (Robbins, Millett, Cacioppe \& Waters-Marsh, 1998). Supportive and trusting manager relations may affect psychological need satisfaction and intentions to leave (Van den Broeck, Vansteenkiste, De Witte \& Lens, 2010). Recent Chartered Institute of Personnel and Development (2009) research highlights the importance of front line managers and how their behavior relates directly to the levels of commitment, motivation and satisfaction reported by employees. A poor relationship with a line manager can be an important reason for individuals leaving their organization, but its significance can be masked as a result of the difficulties associated with exit interviews.

\section{Methodology}

The main purpose of this research is to find out the relationship among work motivation, burnout and intention to leave for the middle level managers in the garment industry in Delhi/NCR.

In the light of a review of literature, the present researcher was of the opinion that no such study has been found on the sample of the middle level managers in garment industry so formulated following null hypothesis:

Ho1: Work motivation as well as it's each dimension will not have any significant relationship with burnout and its dimensions for the middle level managers of the garment industry.

Ho2: Work motivation as well as it's each dimension will not have any significant relationship with intention to leave for the middle level managers of the garment industry.

After several visits made to these garment houses, data were collected. Out of 100 questionnaires distributed, the present researcher got 82 questionnaires back, so 82 questionnaires were included for the purpose of analysis. Thus the sample size comprises of 82 $(\mathrm{N}=82)$.

Thus, a convenient sampling method was used for drawing the sample from 60 garment export houses of Delhi and 40 of NCR (India).

The scale of Aggarwal (1988) was used to measure employees work motivation .This scale consists of 6 factors such as Organizational Orientation, Job Satisfaction, Work Group Relations, Monetary Incentives, Psychological Work Incentives and Dependence. This scale consists of 26 items and each item has 5 alternative answers, one of which is required to be checked, assigning a score of 5 to the most positive response and 1 to the extreme negative 
response. The reliability of this scale is .994 and the item validity was found beyond $1 \%$ level of confidence.

For taping information on burnout the scale developed by Freudenberger (1974) was used. This scale consists of 17 items and has 4 response categories. However, present investigator has modified the scale to 5 points to get also average response, if any, from the sample. Response at " 1 " represents not being true about the respondent and response at " 5 " describes the respondent very well. This scale has 4 factors such as Mental, Emotional, Physical and Social. The reliability and validity of the scale are 0.95 and 0.973 respectively.

For collecting information on intention to leave, two questions were included, each of which consists of 5 justifications or reasons for responding Yes or No.

The data thus collected by using the above questionnaires were treated with the stepwise multiple regression analysis to find out relationship among the dimensions of Work Motivation and Burnout and Intention to leave for the middle level managers of garment industry of Delhi and NCR (India). The data thus analyzed revealed the results which are interpreted and discussed as follows:

\section{Results \& Interpretations}

The following Table 1 of analysis of variance contains sum of square values, mean square value and f- value (Significance level is $5 \%$ ). This table provides analysis of variance among the group and between the groups.

Table 1. Analysis of variance

\begin{tabular}{|c|c|c|c|c|c|c|}
\hline Dependent Variable & Source & $\begin{array}{l}\text { Sum of } \\
\text { Square }\end{array}$ & $\begin{array}{l}\text { Degree } \\
\text { of } \\
\text { Freedom } \\
\end{array}$ & $\begin{array}{l}\text { Mean } \\
\text { Squares }\end{array}$ & F-Ratio & P-Value \\
\hline \multirow[t]{2}{*}{ Job-Satisfaction(JS) } & Regression & 43.443 & 2 & 21.722 & 7.146 & 0.001 \\
\hline & Residual & 243.183 & 80 & 3.040 & & \\
\hline Organizational & Regression & 68.572 & 1 & 68.572 & 6.556 & 0.012 \\
\hline Orientation(OO) & Residual & 847.235 & 81 & 10.460 & & \\
\hline Psychological Work & Regression & 41.387 & 1 & 41.387 & 8.190 & 0.005 \\
\hline Incentive(PWI) & Residual & 409.336 & 81 & 5.054 & & \\
\hline Material & Regression & 58.300 & 1 & 58.300 & 6.951 & 0.010 \\
\hline Incentive(MI) & Residual & 679.338 & 81 & 8.387 & & \\
\hline Work Group & Regression & 59.080 & 2 & 29.540 & 10.719 & 0.000 \\
\hline Relation(WGR) & Residual & 220.462 & 80 & 2.756 & & \\
\hline \multirow[t]{2}{*}{ Dependability(DEP) } & Regression & 208.950 & 3 & 69.650 & 4.257 & 0.008 \\
\hline & Residual & 1292.616 & 79 & 16.362 & & \\
\hline Total Score Of & Regression & 1193.325 & 2 & 596.662 & 4.516 & 0.014 \\
\hline $\begin{array}{l}\text { Work Motivation } \\
\text { (WT) }\end{array}$ & Residual & 10570.145 & 80 & 132.127 & & \\
\hline
\end{tabular}


The above Table 1 warranted the researcher to do further analysis which resulted in the following Table 2 which depicts the summary output of stepwise regression analysis.

Table 2. Stepwise regression analysis of work motivation factors, burnout factors \& intention to leave in middle level managers

\begin{tabular}{|c|c|c|c|c|c|}
\hline $\begin{array}{l}\text { Dependent } \\
\text { Variable }\end{array}$ & $\begin{array}{l}\text { Step } \\
\text { No. }\end{array}$ & $\begin{array}{l}\text { Variable } \\
\text { Removed }\end{array}$ & $\begin{array}{l}\text { Multiple } \\
\text { R }\end{array}$ & $\begin{array}{l}\text { Multiple } \\
\text { R Square } \\
\end{array}$ & $\begin{array}{l}\text { Decrease in } \\
\text { R Square }\end{array}$ \\
\hline \multirow[t]{4}{*}{ Job Satisfaction } & 0 & Physical Burnout & 0.393 & 0.154 & \\
\hline & 1 & Total Burnout & 0.392 & 0.154 & \\
\hline & 2 & Intention to Leave & 0.391 & 0.153 & 0.001 \\
\hline & 3 & Emotional Burnout & 0.389 & 0.152 & 0.001 \\
\hline Organizational & 0 & Mental Burnout & 0.316 & 0.100 & \\
\hline \multirow[t]{4}{*}{ Orientation } & 1 & Intention to Leave & 0.316 & 0.100 & 0 \\
\hline & 2 & Physical Burnout & 0.315 & 0.099 & 0.001 \\
\hline & 3 & Social Burnout & 0.309 & 0.095 & 0.004 \\
\hline & 4 & Emotional Burnout & 0.274 & 0.075 & 0.020 \\
\hline Psychological & 0 & Emotional Burnout & 0.349 & 0.122 & \\
\hline \multirow[t]{4}{*}{ Work Incentive } & 1 & Intention to Leave & 0.349 & 0.122 & 0 \\
\hline & 2 & Physical Burnout & 0.347 & 0.121 & 0.001 \\
\hline & 3 & Total Burnout & 0.325 & 0.106 & 0.015 \\
\hline & 4 & Social Burnout & 0.303 & 0.092 & 0.014 \\
\hline Material & 0 & Total Burnout & 0.319 & 0.102 & \\
\hline \multirow[t]{4}{*}{ Incentive } & 1 & Intention to Leave & 0.318 & 0.101 & 0.001 \\
\hline & 2 & Social Burnout & 0.310 & 0.096 & 0.005 \\
\hline & 3 & Emotional Burnout & 0.298 & 0.089 & 0.007 \\
\hline & 4 & Physical Burnout & 0.281 & 0.079 & 0.010 \\
\hline Work Group & 0 & Mental Burnout & 0.473 & 0.224 & \\
\hline Relation & 1 & Physical Burnout & 0.460 & 0.211 & 0.010 \\
\hline Dependability & 0 & Physical Burnout & 0.386 & 0.149 & \\
\hline Total Score of & 0 & Total Burnout & 0.338 & 0.114 & \\
\hline \multirow[t]{3}{*}{ work motivation } & 1 & Physical Burnout & 0.332 & 0.110 & 0.004 \\
\hline & 2 & Intention to Leave & 0.325 & 0.106 & 0.004 \\
\hline & 3 & Emotional Burnout & 0.319 & 0.101 & 0.005 \\
\hline
\end{tabular}

During backward multiple regression method in the first step when Job Satisfaction factor which is one of the dimensions of work motivation, is entered as dependent variable and all the burnout factors and intention to leave factor as independent variables, it has been observed from Table 2 that in the initial step 0 physical burnout factor is removed but in step 1, 2 and 3 total burnout, intention to leave and emotional factor are removed respectively as they are not the best predicators of job satisfaction. In the last step following Table 2a was observed: 
Table 2a

\begin{tabular}{lllllll}
\hline Regression Coefficients $\mathbf{B}=\left(\mathbf{X}^{\prime} \mathbf{X}\right)^{-\mathbf{1}} \mathbf{X}^{\prime} \mathbf{Y}$ & & & & \\
\hline Effect & Coefficient & $\begin{array}{l}\text { Standard } \\
\text { Error }\end{array}$ & $\begin{array}{l}\text { Std. } \\
\text { Coefficient }\end{array}$ & Tolerance & t-value & p-value \\
& & 0.675 & 0.000 &. & 18.151 & 0.000 \\
CONSTANT & 12.256 & 0.084 & -0.243 & 0.873 & -2.203 & 0.030 \\
Mental Burnout & -0.185 & -0.403 & 0.873 & -3.656 & 0.000 \\
\hline Social Burnout & -0.288 & 0.079 & & &
\end{tabular}

The above Table 2a shows that only mental and social burnout factor determined the job satisfaction level in the middle level manager, so the following regression equation is framed from above table:

$$
Y=12.256-0.185 x_{1}-0.288 x_{2}
$$

Where $\mathrm{Y}$ is job satisfaction, 12.256 is constant or intercept, $\mathrm{x}_{1}$ is the mental burnout and $\mathrm{x}_{2}$ is social burnout factor. It is observed that job satisfaction increases as the amount of mental burnout and social burnout factors decrease. With reference to Table 1 it can be interpreted that F- value 7.146 is highly significant as p value is less than $5 \%$ significance level. So the variance level within the group and between the groups is within permitted limit.

Similarly when Organizational Orientation factor which is one of the dimensions of work motivation, is entered as dependent variable and all the burnout factors and intention to leave factor as independent variables, it has been observed from Table 2 that in the initial step 0 mental burnout factor is removed but in step 1, 2, 3\& 4 intention to leave, physical, social and emotional factor are removed respectively as they are not the best predicators for organizational orientation. In the last step following Table 2b was observed:

Table 2b

\begin{tabular}{lllllll}
\hline \multicolumn{2}{l}{ Regression Coefficients $\mathbf{B}=\left(\mathbf{X}^{\prime} \mathbf{X}\right)^{-\mathbf{1}} \mathbf{X}^{\mathbf{}} \mathbf{Y}$} \\
\hline Effect & Coefficient & Standard Error & Std.Coefficient & Tolerance & t-value & p-value \\
\hline CONSTANT & 21.385 & 1.351 & 0.000 &. & 15.832 & 0.000 \\
Total Burnout & -0.094 & 0.037 & -0.274 & 1.000 & -2.560 & 0.012 \\
\hline
\end{tabular}

The above Table 2b shows that only total burnout factor determined the organizational orientation in the middle level managers, so the following regression equation is framed from above table:

$$
Y=21.385-0.094 x_{1}
$$

Where $\mathrm{Y}$ is organizational orientation, 21.385 is constant or intercept, $\mathrm{x}_{1}$ is the total score of burnout factor. It is observed that organizational orientation increases as the amount of total burn out factor decreases. With reference to Table 1, it can be interpreted that F-value 6.556 is 
highly significant as p value is less than $5 \%$ significance level. So the variance level within the group and between the groups is within permitted limit.

Similarly when Psychological Work Incentive factor which is again one of the dimensions of work motivation is entered as dependent variable, and all the burnout factors and intention to leave factor as independent variables, it has been observed from Table 2 that in the initial step 0 emotional burnout factor is removed but in step 1, 2, 3 and 4 intention to leave, physical, total burnout and social factor are removed respectively as they are not the best predicators for psychological work incentive. In the last step following Table 2c was observed:

Table 2c

\begin{tabular}{lllllll}
\hline Regression Coefficients $\mathbf{B}=\left(\mathbf{X}^{\prime} \mathbf{X}\right)^{-\mathbf{1}} \mathbf{X}^{\prime} \mathbf{Y}$ \\
\hline Effect & Coefficient & Standard Error & Std.Coefficient & Tolerance & t-value & p-value \\
\hline CONSTANT & 18.357 & 0.700 & 0.000 &. & 26.218 & 0.000 \\
Mental Burnout & -0.290 & 0.101 & -0.303 & 1.000 & -2.862 & 0.005 \\
\hline
\end{tabular}

The above Table 2c shows that only mental burnout factor determined the psychological work incentive in the middle level managers, so the following regression equation is framed from above table:

$$
Y=18.357-0.290 x_{1}
$$

Where $\mathrm{Y}$ is psychological work incentive, 18.357 is constant or intercept, $\mathrm{x}_{1}$ is the mental burnout factor. It is observed that psychological work incentive increases as the amount of mental burnout decreases. With reference to Table 1 it can be interpreted that F-value 8.190 is highly significant as p value is less than $5 \%$ significance level. So the variance level within the group and between the groups is within permitted limit.

Similarly when Material Incentive factor which is again one of the dimensions of work motivation, is entered as dependent variable and all the burnout factors and intention to leave factor as independent variables, it has been observed from Table 2 that in the initial step 0 total burnout factor is removed but in step 1, 2, 3 and 4 intention to leave, social, emotional \& physical burnout factor are removed respectively as they are not the best predicators for material incentive factor. In the last step following Table $2 \mathrm{~d}$ was observed:

Table 2d

\begin{tabular}{lllllll}
\hline Regression Coefficients $\mathbf{B}=\left(\mathbf{X}^{\prime} \mathbf{X}\right)^{-\mathbf{1}} \mathbf{X}^{\prime} \mathbf{Y}$ & & & & \\
\hline Effect & Coefficient & Standard Error & Std.Coefficient & Tolerance & t-value & p-value \\
\hline CONSTANT & 17.267 & 0.977 & 0.000 &. & 17.671 & 0.000 \\
Mental Burnout & -0.322 & 0.122 & -0.281 & 1.000 & -2.637 & 0.010 \\
\hline
\end{tabular}


The above Table- $2 \mathrm{~d}$ shows that only mental burnout factor determined the material incentive in the middle level managers, so the following regression equation is framed from above table:

$$
Y=17.267-0.322 x_{1}
$$

Where $\mathrm{Y}$ is material incentive, 17.267 is constant or intercept, $\mathrm{x}_{1}$ is the mental burnout factor. It is observed that material incentive decreases as the amount of mental burnout factor increases. With reference to Table-1 it can be interpreted that F- value 6.951 is highly significant as $\mathrm{p}$ value is less than $5 \%$ significance level. So the variance level within the group and between the groups is within permitted limit.

Similarly when Work Group Relation factor is entered as dependent variable which is one of the dimensions of work motivation, and all the burnout factors and intention to leave factor as independent variables, it has been observed from Table 2 that in the initial step 0 mental burnout factor is removed but in step 1 physical factor is removed as it is not the best predicator for work group relation factor. In the last step following Table 2e was observed:

Table 2e

\begin{tabular}{lclllll}
\hline Regression Coefficients $\mathbf{B}=\left(\mathbf{X}^{\prime} \mathbf{X}\right)^{-\mathbf{1}} \mathbf{X}^{\prime} \mathbf{Y}$ & & & & \\
\hline Effect & Coefficient & $\begin{array}{l}\text { Standard } \\
\text { Error }\end{array}$ & $\begin{array}{l}\text { Std. } \\
\text { Coefficient }\end{array}$ & Tolerance & t-value & p-value \\
\hline CONSTANT & 14.378 & 0.729 & 0.000 &. & 19.716 & 0.000 \\
Emotional Burnout & -0.101 & 0.050 & -0.347 & 0.330 & -2.004 & 0.048 \\
Total Burnout & -0.133 & 0.033 & -0.698 & 0.330 & -4.037 & 0.000 \\
Intention to Leave & -0.382 & 0.029 & -0.301 & 0.334 & -3.026 & 0.063 \\
Social Burnout & -0.183 & 0.071 & -0.260 & 0.330 & -2.390 & 0.042 \\
\hline
\end{tabular}

The above Table 2e shows that emotional, burnout total factor, intention to leave and social burnout factor determined the work group relation in the middle level managers, so the following regression equation is framed from above table:

$$
Y=14.378-0.101 x_{1}-0.133 x_{2}-0.382 x_{3}-0.183 x_{4}
$$

Where $\mathrm{Y}$ is work group relation factor, 14.378 is constant or intercept, $\mathrm{x}_{1}$ is the emotional, $\mathrm{x}_{2}$ is total burnout, $\mathrm{x}_{3}$ is intention to leave and $\mathrm{x} 4$ is social burnout factor. It is observed that work group relation increases as the amount of emotional burnout, total burnout, social burnout and intention to leave factors decrease. With reference to Table 1 it can be interpreted that F- value 10.719 is highly significant as p value is less than $5 \%$ significance level. So the variance level within the group and between the groups is within permitted limit.

Similarly when Dependability factor is entered as dependent variable which is another one of the dimensions of work motivation, and all the burnout factors and intention to leave factor as independent variables, it has been observed from Table 2 that in the initial step 0 physical burnout factor is removed as it is not the best predicator for dependability factor. In the last step 
following Table $2 \mathrm{f}$ was observed:

Table $2 f$

\begin{tabular}{lllllll}
\hline Regression Coefficients B $=\left(\mathbf{X}^{\prime} \mathbf{X}\right)^{-\mathbf{1}} \mathbf{X}^{\prime} \mathbf{Y}$ & & & & \\
\hline Effect & Coefficient & $\begin{array}{l}\text { Standard } \\
\text { Error }\end{array}$ & $\begin{array}{l}\text { Std. } \\
\text { Coefficient }\end{array}$ & Tolerance & t-value & p-value \\
\hline CONSTANT & 22.151 & 1.490 & 0.000 &. & 14.862 & 0.000 \\
Emotional Burnout & -0.184 & 0.073 & -0.273 & 0.927 & -2.517 & 0.014 \\
Mental Burnout & -0.459 & 0.167 & -0.305 & 0.887 & -2.756 & 0.007 \\
Intention toLeave & -2.012 & 0.959 & -0.227 & 0.929 & -2.098 & 0.039 \\
Social Burnout & -.301 & 0.158 & -0.221 & 0.963 & -2.139 & 0.49 \\
\hline
\end{tabular}

The above Table $2 \mathrm{f}$ shows that emotional, mental, intention to leave and social burnout factors determined the dependability factor in the middle level managers, so the following regression equation is framed from above table:

$$
Y=22.151+0.184 x_{1}-0.459 x_{2}-2.012 x_{3} 0.301 x_{4}
$$

Where $\mathrm{Y}$ is dependability, 22.151 is constant or intercept, $\mathrm{x}_{1}$ is the emotional and $\mathrm{x}_{2}$ is mental, $\mathrm{x}_{3}$ is the Intention to leave and $\mathrm{x}_{4}$ is social burnout factor. It is observed that dependability increases as the amount of emotional, mental, intention to leave and social burnout factor decreases. With reference to Table 1 it can be interpreted that F- value 4.257 is highly significant as p value is less than $5 \%$ significance level. So the variance level within the group and between the groups is within permitted limit.

When we combined the score of all the Work Motivation of the individual cases and total score as new variable and entered this variable as dependent variable and all burnout factors and intention to leave factor as the independent variables, then it has been observed from Table 2 that in the initial step 0 burnout factor as a whole is removed but in step 1,2 and 3 physical, intention to leave, emotional factor are removed respectively as they are not the best predicators for work motivation as a whole. In the last step following Table -2g was observed: 
Table $2 g$

\begin{tabular}{lllllll}
\hline Regression Coefficients $\mathbf{B}=\left(\mathbf{X}^{\prime} \mathbf{X}\right)^{-\mathbf{1}} \mathbf{X}^{\prime} \mathbf{Y}$ & & & & \\
\hline Effect & Coefficient & $\begin{array}{l}\text { Standard } \\
\text { Error }\end{array}$ & $\begin{array}{l}\text { Std. } \\
\text { Coefficient }\end{array}$ & Tolerance & t-value & p-value \\
\hline CONSTANT & 105.865 & 4.593 & 0.000 &. & 23.051 & 0.000 \\
Mental Burnout & -0.894 & 0.453 & -0.212 & 0.969 & -1.973 & 0.052 \\
Social Burnout & -0.928 & 0.492 & -0.203 & 0.969 & -1.884 & 0.063 \\
\hline
\end{tabular}

The above Table $2 \mathrm{~g}$ shows that mental and social burnout factors determined the total work motivation factor in the middle level managers, so the following regression equation is framed from above table:

$$
Y=105.865-0.894 x_{1}-0.928 x_{2}
$$

Where $\mathrm{Y}$ is total score of work motivation, 105.865 is constant or intercept, $\mathrm{x}_{1}$ is the mental and $\mathrm{x}_{2}$ is social burnout factor. It is observed that total score of work motivation increases as the amount of mental and social burnout factor decreases. With reference to Table 1 it can be interpreted that F- value 4.516 is highly significant as p value is less than $5 \%$ significance level. So the variance level within the group and between the groups is within permitted limit.

The above results clearly indicate that some dimensions of work motivation do have relationship with the intention to leave and burnout and its dimensions. So, the hypothesis Ho1 and Ho2, which states that 'Work motivation as well as it's each dimension will not have any significant relationship with burnout and its dimensions for the middle level managers of the sample' and 'Work motivation as well as it's each dimension will not have any significant relationship with intention to leave for the middle level managers of the sample', stand rejected.

\section{Discussion}

As it is evident from the Table 2a, social burnout and mental burnout came out to be the predictor of the same dimension for the middle managers of garment industry of Delhi/NCR. For organization orientation dimension of work motivation for middle level managers (Table-2b) only total burnout, is figured out to be the best predictor.

For psychological work incentives mental burnout emerged important predictor for the middle level managers (Table 2c). When we refer Table 2d, we will find that the analysis has revealed that mental burnout has been found out to be the common predictor of material incentives for middle level managers. Social burnout dimension emerged as the common predictor of work group relations for the middle level managers (Table 2e), emotional burnout dimension and total burnout along with the intention to leave came out to be the predictors of work group relations.

When we look at the Table $2 \mathrm{f}$, we find that emotional, mental, social factors of burnout emerged as the common predictors of dependability dimension of work motivation for the 
middle level, managers. Intention to leave comes out as a predictor (along with emotional, mental and social dimensions of burnout) of dependability for the middle level managers.

It is evident from the Table $2 \mathrm{~g}$, that mental burnout and social burnout emerged as important predictors of total work motivation for middle level managers.

Turnover intention was found positively related to mental burnout. When mental burnout was high employees were more interested in looking for other jobs and were planning to quit. These results are consistent with findings of Lieter and Maslach (2009), Schaufeli and Bakker (2004).

Work group relations, collegial relationship and dependency that is how superior treats his subordinates also influence intention to leave decision of employee because when work group relations with superiors and colleagues is not good, an employee feels irritated and intends to leave the current organization. These results are consistent with findings of Van den Broeck, Vansteenkiste, De Witte \& Lens, 2010 \&Chartered Institute of Personnel and Development (2009), Houkes I. (2001), Winter (2000).

\section{Managerial Implications}

The proposed research will be significant for managers who can understand the existence of burnout and importance of healthy work environment in an organization. Managers can help their employees to deal with job stressors so that employees can enjoy their job and that is likely to influence their work motivation. Acknowledgment of burnout is important for developing good practices at workplaces. The negative consequences of burnout provide clear evidence of the importance of avoiding burnout in organizations.

Hence, the significance of this research is three-fold. The results of this study will help 1) employees in at any point in their career to understand and recognize negative stressors and prevent burnout; 2) findings will help managers to deal with stress related problems at work by having and maintaining healthy work culture and 3) design and implement intervention programs for burnout prevention.

\section{Conclusion \& Recommendation}

Looking at the above findings it becomes pertinent to mention that all dimensions of burnout have more or less impact on work motivation of middle level managers but mental burnout has more impact on work motivation of middle level managers so, if these dimensions of burnout particularly mental burnout which affect work motivation and its various dimensions are taken care by taking into consideration work environment, work group relations and leadership styles the work motivation of the middle level managers in garment industry of Delhi/NCR would be enhanced. As far as intention to leave is concerned it has been found that it is influenced negatively by the dimensions of burnout for middle level managers.

Since the present researcher has worked on the relationship between work motivation, burnout and intention to leave for the middle level managers of garment industry (a case study of Indian garment industry).The relationship among these variables as well as their dimensions have been explored. It is suggested that in the further researches the styles of leadership variable may be taken as another variable to see its relationship with the work motivation and its 
dimensions for the sample of middle level managers in garment industry of Delhi/NCR.

\section{Limitations of Study}

The main limitation of this study is that, information could not be collected from large sample of middle level managers because of their non availability and busy schedules.

\section{References}

Agarwal, K. G. (1978a). Self Role and Stratus: Stratification Theory of Work Motivation. New Delhi: Sterling

Agarwal, K. G. (1978b). Work satisfaction and mental health. Indian Educational Review, 14, 22-29.

Boyas, J., \& Wind, L. H. (2010). Employment-based social capital, job stress, and employee burnout: A public child welfare employee structural model. Children and Youth Services Review, 32, 380-388. http://dx.doi.org/10.1016/j.childyouth.2009.10.009

Catherine, M. G. (2002). Employee turnover: a study of private clubs in the USA. International Journal of Contemporary Hospitality Management, 3, 106-113.

Cotton, J. L., \& Tuttle, J. M. (1986). Employee Turnover: A Meta-Analysis and Review with Implications for Research. Academy of Management Review, 11(1), 55-70.

Densten \& Iain, L. (2005). The Relationship between Visioning Behaviours of Leaders and Follower Burnout. British Journal of Management, 16(2), 105-118. http://dx.doi.org/10.1111/j.1467-8551.2005.00428.x

Freudenberger, H. J. (1974). Staff burnout. Journal of Social Issues, 30(1), 159-165. http://dx.doi.org/10.1111/j.1540-4560.1974.tb00706.x

Gray-Stanley, J. A., \& Muramatsu, N. (2011). Work stress, burnout, and social and personal resources among direct care workers. Research in Developmental Disabilities, 32, 1065-1074. http://dx.doi.org/10.1016/j.ridd.2011.01.025

Houkes, I. (2001). Specific relationship between work characteristics and intrinsic work motivation, burnout \&turnover intention. European Journal of work \& organizational psychology, 10, 1-23. http://dx.doi.org/10.1080/13594320042000007

Jacob, W. (1994). Measuring Workers' Burnout and Intention to leave. International Journal of Manpower, 15(1), 4-14. http://dx.doi.org/10.1108/01437729410053590

Lamude, K. G., \& Furno, L. D. (1996). Burnout and managers' tactics of influence. Journal of Percept Mot Skills, 83(1), 193-194. http://dx.doi.org/10.2466/pms.1996.83.1.193

Leiter, M. P., \&Maslach, C. (2009). Nurse turnover: the mediating role of burnout. Journal of Nursing Management, 17, 331-339. http://dx.doi.org/10.1111/j.1365-2834.2009.01004.x

Maslach, C., Schaufeli, W., \& Leiter, M. P. (2001). Job burnout. Annual Review of Psychology, 52, 397-422. http://dx.doi.org/10.1146/annurev.psych.52.1.397 


\section{Macrothink}

Business and Management Horizons

ISSN 2326-0297

2013, Vol. 1, No. 2

Pool S. W. (1997). The relationship of job satisfaction with substitutes of relationship leadership behavior and work motivation. Journal of psychology, 131(3), 271-283. http://dx.doi.org/10.1080/00223989709603514

Robbins, S. P., Millett, B., Cacioppe, R., \& Waters-Marsh, T. (1998). Organizational behavior: Leading and managing in Australia and New Zealand. Sydney: Prentice Hall.

Schaufeli, W. B., \& Bakker, A. B. (2004). Job demands, job resources and their relationship with burnout and engagement: A multisample study. Journal of Organizational Behavior, 25, 293-315. http://dx.doi.org/10.1002/job.248

Smith, P. C. (1992). In pursuit of happiness. In C. J. Cranny, P. C. Smith, \& E. F. Stone (Eds.), Job satisfaction (pp. 5-19). New York: Macmillan.

Tett, R. P., \& Meyer, J. P. (1993). Job Satisfaction, Organizational Commitment, Turnover Intention and Turnover: Path Analyses Based on Meta-Analytic Findings. Journal of Personnel Psychology, 46, 259-293.

Tony, T. S. K., \& Lilian, M. (2012). Job stress, perceived inequity and burnout among school social workers in Hong Kong. International Social Work, 48(4), 467-483.

Van den Broeck, A., Vansteenkiste, M., De Witte, H., Soenens, B., \& Lens, W. (2010). Capturing autonomy, relatedness and competence at work: Construction and validation of the Work-related Basic Need Satisfaction Scale. Journal of Occupational and Organizational Psychology, 83, 981-1002. http://dx.doi.org/10.1348/096317909X481382

Winter, R. (2000). The Academic Work Environment in Australian Universities. Journal of Higher Education R\&D, 21(3).

\section{APPENDIX}

\section{SECTION-A}

Below are given 26 questions. Please tick one of the alternative answers given in each question.

1. All in all how satisfied are you with your job?

a) Very satisfied with my job

b) Neither satisfied nor dissatisfied

c) Fairly satisfied

d) Somewhat dissatisfied

e) Very dissatisfied with my job.

2. Considering your skills and efforts you put into the job how satisfied are you with your pay?

a) Very satisfied with my job 


\section{Macrothink}

b) Neither satisfied nor dissatisfied

c) Fairly satisfied

d) Somewhat dissatisfied

e) Very dissatisfied with my job

3. To what extent do you feel about the way tea breaks, lunch breaks, hours of work and the like are handled in your office?
a) Very satisfied
b) Neither satisfied nor dissatisfied
c) Somewhat satisfied
d) Somewhat dissatisfied
e) Very dissatisfied

4. How much satisfied do you feel about your Organization employees benefits as compared to other similar Organizations?
a) Very satisfied
b) Neither satisfied nor dissatisfied
c) Somewhat satisfied
d) Somewhat dissatisfied
e) Very dissatisfied

5. How much satisfied do you feel about your chances of promotion in your Organization?

a) Completely satisfied

b) Neither satisfied nor dissatisfied

c) Fairly satisfied

d) Somewhat dissatisfied

e) Very dissatisfied

6. To what extent you like the kind of work you do in your Organization?
a) It is exactly the kind of work I like best
b) I like it very much
c) It is alright
d) I do not like it very much
e) I dislike it very much 


\section{Macrothink}

Business and Management Horizons

ISSN 2326-0297

2013, Vol. 1, No. 2

7. How do people here work in your Organization?

a) To keep their job, make money, get promoted, do a satisfied job\& because other people in their work group except.

b) To keep their job, make money, get promoted and for satisfaction of a job well done.

c) To keep their job, make money\& get promoted

d) To keep their job\& make money.

e) Just to keep their job \& for not being chewed out.

8. To what extent do things about working here (People policies/conditions) that discourage you from working here?

a) Not practically anything around here encourages me to work here.

b) Not most around here encourage me to work here.

c) About as many things discourage me as encourage me

d) Yes, great many things around here discourage me to work here

e) Yes, practically everything around here encourage me to work here

9. To what extent does your job give you a chance to use your best abilities to do things you are best at?

a) To a very great extent

b) To a considerable extent

c) To a some extent

d) To a very little extent

e) Not at all

10. To what extent does your work here help you learn more about your profession?

a) To a very great extent

b) To a great extent

c) To a some extent

d) To a very little extent

e) Not at all

11. To what extent do you agree that if you had a chance to do some kind of work for same pay in another Organization, would you still stay here?

a) I would stay in this organization 
b) I would stay if things seem to change here

c) I can not say

d) I would prefer to go if conditions are better in the other organization

e) I would prefer to go to other organization

12. To what extent the people who make decisions are aware of problems at lower levels in the organization?

a) To a very great extent

b) To a considerable extent

c) To a some extent

d) To a very little extent

e) Not at all

13. To what extent do you agree that the work assignments are well planned in your Organization?
a) Extremely well planned
b) Very well planned
c) Fairly well planned
d) Not too well planned
e) Not well planned

14. To what extent do people in your work group show you how to improve your performance?

a) To a very great extent

b) To a considerable extent

c) To a some extent

d) To a very little extent

e) Not at all

15. To what extent do find your immediate superior talks to you in the appreciating \& encouraging way?
a) Always
b) Most of the time
c) Sometimes
d) A few times 


\section{Mll Macrothink}

Business and Management Horizons

ISSN 2326-0297 2013, Vol. 1, No. 2

e) Never

16. To what extent do you agree that your immediate superior talks to you in giving directions \& suggestions?
a) Always
b) Most of the time
c) Sometimes
d) A few times
e) Never

17. To what extent do you agree that your immediate superior talks to you in criticizing way \& refuses to help?
a) Always
b) Most of the time
c) Sometimes
d) A few times
e) Never

18. To what extent do you agree that your immediate superior talks to you in harassing way \&asks for explanation?
a) Always
b) Most of the time
c) Sometimes
d) A few times
e) Never

19. To what extent do you have confidence\& trust in the people in your work group?
a) To a very great extent
b) To a considerable extent
c) To a some extent
d) To a very little extent
e) Not at all

20. How free do you feel to discuss your personal problems with your immediate superior?

a) I always feel free to discuss 


\section{Macrothink}

b) I usually feel free to discuss

c) Sometimes I feel free to discuss

d) Only once a while

e) Never feel free

21. Suppose you were having some sort of difficulty in your job. To what extent do you feel your immediate superior would be willing to go out of way to help you if you ask for it?
a) To a very great extent
b) To a considerable extent
c) To a some extent
d) To a very little extent
e) Not at all

22. To what extent do the members of staff in your work group make an effort to avoid creating problems?
a) To a very great extent
b) To a considerable extent
c) To a some extent
d) To a very little extent
e) Not at all

23. To what extent do you feel you are responsible for your work?
a) To a very great extent
b) To a considerable extent
c) To a some extent
d) To a very little extent
e) Not at all

24. To what extent do you feel free to plan your own work?
a) To a very great extent
b) To a considerable extent
c) To a some extent
d) To a very little extent
e) Not at all 


\section{Macrothink}

25. To what extent do you feel you are doing useful work here?

a) To a very great extent

b) To a considerable extent

c) To a some extent

d) To a very little extent

e) Not at all

26. How much satisfied do you feel with the recognition your work gets?

a) Very satisfied

b) Neither satisfied nor dissatisfied

c) Somewhat satisfied

d) Somewhat dissatisfied

e) Very dissatisfied

\section{SECTION B}

Below are the eighteen questions/statements. Please encircle the number given against each question/statement. The value range is from 1-5. "1" represents not being true for you and "5" decribes you very well.

1. I get tired more easily. $1 \begin{array}{llllll}1 & 2 & 3 & 4 & 5\end{array}$

2. I feel fatigued rather than energetic. $\quad \begin{array}{lllll}1 & 2 & 3 & 4 & 5\end{array}$

3. People annoy me by telling me "you don't look so good lately". $\quad \begin{array}{lllll}1 & 2 & 3 & 4 & 5\end{array}$

4. I am working harder \&harder but accomplishing less. $\begin{array}{lllll}1 & 2 & 3 & 4 & 5\end{array}$

5. I am increasingly cynical and disenchanted. $\quad \begin{array}{rrrrr}1 & 2 & 3 & 4 & 5\end{array}$

6. I often experience unexplained sadness. $\quad \begin{array}{lllll}1 & 2 & 3 & 4 & 5\end{array}$

7. I am forgetting appointments, deadlines or personal possessions more frequently. 12345

8. I have become more irritable.

$\begin{array}{lllll}1 & 2 & 3 & 4 & 5\end{array}$

9. I am more short-tempered.

$1 \quad 2 \quad 3 \quad 4 \quad 5$

10. I am disappointed with people around me.

$\begin{array}{lllll}1 & 2 & 3 & 4 & 5\end{array}$

11. I am seeing family members and close friends less frequently. $\quad \begin{array}{lllll}1 & 2 & 3 & 4 & 5\end{array}$

12. I am too busy to do even routine things like make phone calls or read reports or send cards to friends. $\quad \begin{array}{llllll}1 & 2 & 3 & 4 & 5\end{array}$ 


\section{Macrothink}

Business and Management Horizons

ISSN 2326-0297

2013, Vol. 1, No. 2

13. I am experiencing increased physical complaints (aches, pains, headaches, lingering colds). $\begin{array}{lllll}1 & 2 & 3 & 4 & 5\end{array}$

14. I feel disoriented when the activity of the day comes to a halt.
15. Joy is elusive.
$\begin{array}{lllll}1 & 2 & 3 & 4 & 5\end{array}$
16. I am unable to laugh at a joke about myself.
$\begin{array}{lllll}1 & 2 & 3 & 4 & 5\end{array}$
17. I have very little to say to people?
$\begin{array}{lllll}1 & 2 & 3 & 4 & 5\end{array}$

\section{SECTION- C}

1. If opportunities available, would you intend to join some other organization? If yes, please give reasons in order of priority.

(i)

(ii)

(iii)

(iv)

( $v)$

2. Do you have any intention to leave your organization? If yes, please give reasons in order of priority.

(ii)

(iii)

(iv)

(v)

\section{SECTION-D}

\section{PERSONAL- INFORMATION}

1) Name (Optional).

2) Gender: Male/Female.

3) Educational qualification

4) Your age Group (in years)

5) Marital status: Please tick the appropriate 
(i) Married

(ii) Single

(iii) Separated

6) Number of dependents

7) Experience in the current job for (in years).

8) Total work experience (in years).

9) Designation.

10) Number of promotions earned (if any)....

11) Gross salary per month

12) Work pattern of my organization is:

(i) Rotating shifts

(ii) Fixed shift(iii) Standard hours

Any other inputs you would like to share

Thank you very much once again for your co-operation.

\section{Copyright Disclaimer}

Copyright reserved by the author(s).

This article is an open-access article distributed under the terms and conditions of the Creative Commons Attribution license (http://creativecommons.org/licenses/by/3.0/). 